\title{
Reference Work and the War
}

Ways in which the war has affected reference work, as observed in an active university library by its reference librarian.

Beinning with the Sunday Japan dropped bombs on Pearl Harbor, the University of California Library, in common with many other large libraries located at strategic points throughout the United States, became a busy center for war information. The shipyards and other war plants around the San Francisco Bay, the various branches of the armed services with headquarters in this area, research laboratories, and private citizens turned to the library for assistance. It has been the interesting task of the members of the reference division to supply their requests for information promptly and comprehensively. So varied and timely have been the demands for reference service that it might almost be said that the history of the war has been reflected in the work of this division since Dec. 7, 194I.

Some of the agencies which have depended upon the university library for reference assistance have been the Office of War Information, the Office of Strategic Services, the Army Map Service, the Federal Bureau of Investigation, the Military Intelligence Division, the Kaiser Company, and the Richmond shipyards.

These organizations have frequently asked for biographical facts about individuals prominent in the news, for directory information, for the library's holdings of newspapers from a specific area, or for a list of dictionaries and grammars available in the library for a given language or dialect. Questions of this type have usually been answered at once. Not all of their requests, however, have been disposed of so readily. Typical of those inquiries which have required an extensive search have been: the effect of priorities upon unemployment, conversion of ships to war needs, sea transport of refrigerated produce in wartime, a list of references relating to Kamchatka, and the vegetation of the islands in the entire Pacific area.

After receiving numerous requests for the identification of descendants of individuals for whom ships were being named, it was gratifying to have the superintendent of one of the shipyards offer the reference staff passes to a ship launching.

The reference division has frequently been called upon for information to be used in broadcasts or to be published in newspapers. For radio use many of the inquiries have related to the pronunciation of a given word, usually a name or place new in the news. From the newspaper offices the demand has been for pictures and for general information about a given area, for example, its size, population, climate, and living conditions.

The need for the exercise of imagination on the part of the reference librarian is well illustrated by the following incident. One morning a telephone call was received from San Francisco for the exact location in Spain of San Sorigen. I 
started to verify the place in Espasa, when I suddenly realized the inquirer must be confused by sans origine. I asked her if she had received a cable with this designation. When she replied in the affirmative, I explained that it was the term used on cables to show that the point of origin had been deleted in accordance with censorship regulations.

It has been greatly to our advantage to have a file of the Engineering Index supplementary cards, as this service is more up to date than our other technical and scientific bibliographies. This record has been used as the source for recent references on electric welding machines; flight test procedures; industrial uses of synthetic rubbers; uses of plastics for aircraft construction, to conserve rubber, and to replace metals; and the use of creosote mixtures in Diesel engines.

The procedure relating to one of the technical questions of a confidential nature may be of interest. For several days one of the assistants and I spent considerable time searching for periodical references which were abstracted at once by a member of the engineering faculty, if an abstract was not readily available. $\mathrm{He}$ forwarded his notes to Washington and received a telegram requesting the sources used for the references, which were promptly supplied. The abstracts were then sent to someone in England, who cabled inquiring where in England files of the Engineering Index could be found. By consulting the $W$ orld List of Scientific Periodicals, an English publication, we furnished the desired information. We naturally should like to know, but probably never shall, why the University of California rather than some other library was called upon for this reference service.

\section{Topics of Questions}

The interest of the students and the taxpayers in the war and defense program has been reflected in their questions. At first their inquiries were in regard to such topics as air raid precautions, chemical warfare, incendiary bombs, blackouts, effects of the draft, and the results of the aluminum drive; then, as the war progressed, they showed interest in commando tactics, propaganda, our aid to the allies, uses of plastics, communism and the war, victory gardens, and canning of fruits and vegetables. And recently Wilson's Fourteen Points and the underlying principles of the League of Nations have been reviewed.

There has been an increased demand by the nontechnical reader for technical books on blueprints, machine tools, molds used in casting, shipbuilding, and production control. He has also been interested in "refresher" material to aid him in reviewing elementary mathematics, physics, and chemistry.

Postwar planning has been one of the subjects for which there have been frequent inquiries from the students, the general public, and civilian employees of the service branches. This is encouraging, as librarians must be aware of the problems to be solved after the war. Just as libraries aided industrial concerns by furnishing references on the conversion of plants to wartime production, so may they expect to be called upon for literature relating to reconversion after the war.

Although theoretically the assignments for the men in the Army and Navy training programs have been largely to textbooks, the reference division has been called upon frequently for guidance in their studies. Requests from the Navy trainees have been for suggestions for 
books to be used in reviewing mathematics, physics, and chemistry; for biographies of the authors of books read for book reports; and for advice on the selection of subjects for talks in public speaking classes.

Now that the Army's foreign language program has advanced from an intensive language study into a survey of the geography and culture of a given area, the students are asking for assistance in finding references relating to the agriculture, the economic and social conditions, and the politics and government of their assigned countries. Many of these students have expressed appreciation of the library's unusually fine collection of foreign periodicals and documents.

In addition to reference service to the trainees on campus, requests for lists of references on a wide variety of subjects have been received from men stationed in camps which have limited library facilities.

War reference work has not been without its humorous situations. A woman telephoned from San Francisco one day asking for the pay and subsistence rate of an officer of a given grade in the Navy. After I answered her question, she said, "You may be interested in knowing why I am requesting this information." Then she went on to say that she had recently seen an announcement in the paper of the promotion of her ex-husband and she wondered how much more alimony she might expect.

\section{Maps}

The importance of a well-organized, extensive collection of maps has been demonstrated in the almost daily use of the resources of our map collection by military and faculty personnel. Battles have been fought in regions never before envisaged as of military importance and rarely, if ever, visited by English-speaking persons. Maps have been essential in the intensive search for information about these remote areas. Supplemental to the maps have been the hundreds of important bits of information located in travelers' descriptions, in reports of scientific expeditions, and in technical periodicals.

Before the virtual embargo on the shipment of maps issued by military agencies in foreign countries, which preceded the outbreak of the war by several months, the library had made good progress in its deliberate program of collecting such foreign maps. As a result the Army Map Service has located here several hundred maps which merited reproduction and which were not discovered elsewhere in the United States. Other organizations which have used our map collection have been the Western Defense Command, the Military Intelligence Division, and the Office of Strategic Services.

Two large bulletin boards near the entrances to the main reading room have presented a series of large- and small-scale maps and charts selected to illustrate the progress of the war. The maps have been changed as the regional emphasis of the war news has shifted. Interest in these map displays has been shown by the number of individuals who have stopped to study them as well as by the inquiries regarding the maps and their possible acquisition.

\section{Pamphlets and Posters}

This library, designated as one of the war information centers, receives display pamphlets and posters of World War II interest. Posted on a special bulletin board, they are grouped by organization issuing the material, for example, the 
U.S. Office of War Information, the British Information Services, and Fighting France. These exhibits are changed on the first and fifteenth of every month. Some of the subjects emphasized have been economics of peace and war, health, recreation, postwar planning, and the Netherlands, the last named being a timely exhibit arranged for Princess Juliana's recent visit.

A collection of Russian periodicals and publications of learned societies, outstanding in the West, has enabled the library to provide the results of research by the Russians on synthetic rubber and on surgery at the front and, curiously enough, articles on their discoveries relating to tropical medicine.

One very practical request was for descriptions in German and Russian of antiaircraft guns. As part of the lend-lease program, a merchant ship from Russia was being equipped with guns of this type. The men responsible for their care and operation knew no English, so that it was necessary for us to assemble articles published in Russian and German, with which they were familiar. Two Russian sailors, with an interpreter, came to the library for the references which we had selected and also for technical dictionaries. When the materials were returned, the interpreter expressed the gratitude of the Russians, who smiled and nodded approval.

Some account of the war work of the Reference Division of the University of California Library has been given by suggesting the variety and importance of the reference questions. The actual work involved has been a highly stimulating experience to the members of the staff. They have had a sense of rich reward in the realization of an active participation in the war effort. The future holds the responsibility of serving in unpredictable ways the personnel already concentrating with determined purpose in this key area adjacent to the Pacific theatres of war.

\section{A Library Reorganizes through Building \\ (Continued from page 32I)}

state board of education. It provided, however, that the superintendent of public instruction would be included as an ex officio member of the board and that the state library was to be the administrative center for state public library development.

As with any developing institution, the reorganization of the state library is as yet incomplete. The goal set for a complete service in the new building as of r94I included a staff of thirty-two professional and thirty-one positions of other character and a budget of at least $\$ 200,000$. These have not yet been achieved, although substantial progress has been made. A comparison of advances made in the decade, however, show very definite, sustained improvement, and the prospects of the library's reaching a period of ever-increasing usefulness to the commonwealth are, even now, encouraging.

In conclusion it may be said that the library has been extremely fortunate in having been able to make a planned reorganization for a new building rather than having been faced with a sudden reorganization in unplanned quarters. Occupancy of the building has modified in no major respect the routine and organization that were determined at the beginning. 